\title{
Diplomacy in the Age of Mongol Globalization: an Introduction
}

\author{
Francesca Fiaschetti* \\ Universität Wien, Wien (Austria) \\ francesca.fiaschetti@univie.ac.at
}

In building his empire, Chinggis Khan (r. 1206-27) alternatingly combined military and diplomatic efforts to integrate his subjects and neighbors into his project of conquest. He brought forth traditions of the Inner Asian cultural complex, ${ }^{1}$ and expanded them even further to set up a network of more or less formalized dependencies. Such a network was meant to determine with whom one could trade, with whom one could intermarry and against whom one would fight - something which did not necessarily prevent the trade exchanges but rather complemented them (e.g. forced trade). On the one hand, tracing the Turko-Mongolian precedents of these patterns of interaction is fundamental to situate Chinggisid diplomacy in the context of Eurasian diplomacy. ${ }^{2} \mathrm{On}$ the other hand, it is important to ask: what made the diplomatic practices of the medieval Mongols distinctively Chinggisid?

Traditional scholarship has investigated this question by looking mainly at chancellery documents. ${ }^{3}$ The Mongols in fact enabled the exchange of practices

* I am grateful to Marie Favereau, who contributed to shaping the concept of the conference and commented on a previous draft of this introduction. I also wish to thank Márton Vér, Konstantin Golev and Boriana Antonova Goleva for their suggestions and comments. All shortcomings remain my own.

1 On these traditions, see for example, Sinor, Denis, "Diplomatic Practices in Medieval Inner Asia", in Bosworth, C.E., Issawi, C., Savory R., and A.L. Udovitch (eds.), Essays in honor of Bernard Lewis: the Islamic world from Classical to Modern Times (Princeton: The Darwin Press, 1989): pp. 337-55.

2 For a description of the main practices of Eurasian diplomacy in East Asia see Skaff, Jonathan K., Sui-Tang China and Its Turko-Mongol Neighbors. Culture, Power, and Connections (Oxford: Oxford University Press, 2012 [Oxford Studies in Early Empires]).

3 See, among others, Voegelin, Eric, "The Mongol Orders of Submission to European Powers, 1245-1255", Byzantion, XV (1940-1): pp. 378-413 = reprinted in a revised form, with English translation for all texts in: Sandoz, Ellis (ed.), Published Essays: 1940-1952 (Missouri: University 
of diplomatic communication in different cultural spheres and added elements of their own, thus establishing a tradition which affected the juridical and diplomatic systems of huge parts of Eurasia for centuries. What unified these practices was a specific terminology and rhetoric derived from the Mongols' worldview. Studies on the period of the United Empire (120659) have highlighted how these rules of interaction were framed as part of Chinggis' jasaq, thus constituting, as famously analysed by Voegelin, a proper set of laws that subjects (de iure or de facto) of the Mongols had to respect. ${ }^{4}$ It is exactly this connection with the creation of a new empire, that makes the diplomatic practices of the period distinctively Chinggisid. The fundamental function of the jasaq was the construction of the Mongols' authority, and the constant narration (or re-narration) of the origin of this authority. Thus, diplomatic practices from the period offered a distinctive narrative framework and new forms of interaction, which were functional to the universalistic purposes of the Mongols, allowing for unity and uniformity in the highly fragmented landscape of medieval Eurasia.

In matters of Realpolitik, Chinggisid diplomacy built upon a complex mix of establishing kinship ties and economic domination, building a hierarchy of foreigners by giving interest to some and ignoring others. This was achieved by including a multitude of people from different ethnicities and backgrounds, languages and rituals in the medieval Mongols' system of diplomacy.

These dynamics of inclusiveness come more prominently to the fore starting from the second half of the thirteenth century, with the fragmentation of the empire into four khanates. By then, Chinggisid diplomacy had taken on a different role, also adopting a new rhetoric: intra-Mongol conflicts among members of the imperial lineage had to be dealt with alongside the interaction with foreign powers, and often the two issues overlapped in the framework of diplomatic communication.

As a consequence, imperial edicts often became nuanced communication between rulers, either to state authority in the case of intra-Mongol disputes, or to seek alliances against common enemies. During this shift from "non-negotiation" to compromise - as famously analysed by Aigle ${ }^{5}$ - the

of Missouri Press, 200o): pp. 76-125; Grigor'ev, Arkadiij Pavlovič, Mongol'skaja diplomatika $X I I I-X V v v$ : čingizidskie zhalovannye gramoty (Leningrad: Izdatel'stvo Leningradskogo universiteta, 1978); Biran, Michal, "Diplomacy and chancellery practices in the Chagataid Khanate: some preliminary remarks", OM, LXXXVIII (2008): pp. 369-93, esp. 386-9.

4 Voegelin, "The Mongol Orders".

5 Aigle, Denise, "From 'Non-Negotiation' to an Abortive Alliance. Thoughts on the Diplomatic Exchanges between the Mongols and the Latin West", in Ead., The Mongol Empire between 
mediation of personnel specializing in the narratives and ways of communication of the populations the Mongols dealt with, in the East as well as in the West of Eurasia, became more and more prominent in the diplomatic process. Translators, scribes, advisors and intellectuals voiced the Mongols' demands in foreign tones, performing foreign rituals, and in ways more apt to achieve a diplomatic compromise. ${ }^{6}$ However, as shown in this volume by Na'ama $\mathrm{O}$. Arom in the case of Abaqa's diplomatic communication with the Latin West, the formulas and ways of proclaiming Chinggisid authority did not disappear altogether, thus constituting an element of continuity with the period of the United Empire.

Against the background of the political changes witnessed in Mongol Eurasia between the 13th and 14th centuries, questions of continuity and change become important in understanding the evolution of Mongol diplomacy in this period. As various papers in this volume show, the element of rituality in diplomatic exchanges offers interesting examples to analyze these issues. Qiu Yihao's paper takes gift-diplomacy as a case-study to investigate how Chinggisid diplomacy moved from patterns of Inner Asian tradition, to further develop new performances and meanings alongside the creation of the Mongol Empire. Gifts and tributes in Chinggisid diplomacy shifted from signaling a hierarchical relation, to displaying an extension of the Mongol Empire.

The material aspects of diplomacy come to the fore also in Jana Valtrovás paper, as she looks at various aspects of William of Rubruck's mission, and at the cultural challenges of the Western missionary in dealing with the abovementioned gift-policy. Her paper addresses important questions regarding the multiple purposes of the envoys travelling to and from the Mongol courts, their biases and the ways in which they dealt with the local contexts and communities that they encountered.

By analyzing new sources from the Chagataid Khanate, Márton Vér further investigates the daily practices of diplomacy. His paper provides new insights on the scale and organization of diplomatic missions, on the practical aspect

Myth and Reality (Leiden: Brill, 2014): pp. 159-98. A similar shift is present in the diplomatic correspondence of the Yuan dynasty (1260-1368), as analysed in Fiaschetti, Francesca, "Tradition, Innovation and the Construction of Qubilai's diplomacy", Ming Qingyanjiu, XVIII (2014): pp. 65-96.

6 Famous examples of cultural mediation in the diplomatic correspondence of the period are analysed in Meyvaert, Paul, "An Unknown Letter of Hulagu, Il-Khan of Persia, to King Louis IX of France", Viator, XI (1980): pp. 245-59; Aigle, Denise, "The Letters of Eljigidei, Hülegü and Abaqa - Mongol Overtures or Christian Ventriloquism?", Inner Asia, VII (2005): pp. 143-62. 
of the usage of the jam (post-system), and on the various types of elčis (envoys) who used it.

Yet, envoys were not the only agents involved in the diplomatic process. As the author of this introduction shows in her paper, in China under Mongol rule, the bureaucratization of state activities led to the inclusion, in the Mongols' interaction with their neighbours, of various kinds of individuals: from bureaucrats to scholars, and even generals, all of whom contributed, with their own perspectives, to build Yuan diplomacy.

Furthermore, the contents of diplomatic exchanges were often included also in works of official historiography, shaping the narratives about the Mongols among their neighbours and among the submitted populations. The representation of Mongol diplomatic dynamics in these records was not always homogeneous, or even correct, and this also impacted how Mongol history was portrayed. Bayarsaikhan Dashdondog addresses this question by looking at the interesting matter of Mongol-Ismaili relations during the Alamut period, and at the various narratives concerning the death of Rukn al-Dīn Khur-Shāh during his diplomatic mission to the Mongols.

This is a notable example of how regional dynamics became entangled with intra-Mongol conflicts, something that Na'ama O. Arom also investigates in her review of how the Ilkhanate's "in-ger" and foreign diplomacy evolved between the reigns of Hülegü (r. 1256-65) and Abaqa (r. 1265-82). The Ilkhanid-Jochid conflict is also taken up in Konstantin Golev's paper from the viewpoint of authority - specifically, how it was expressed in a fragmenting Chinggisid world, and how the accusation of witchcraft was used as an argument in real or fictive intra-Mongol diplomatic communications.

With Marco Ciocchetti's paper, the relation between diplomatic practices and historiography is brought to the Latin West. By comparing Italian and German chronicles, Ciocchetti provides new data for a more nuanced representation of the image of the Mongols in Europe: at times seen as a menace, at times as a possible ally, their representation varied according to local interests and the political needs of the papacy and various European regions.

Most of the papers in this volume were originally presented at the conference "Diplomacy in the Age of Mongol Globalization", organized by Francesca Fiaschetti and Marie Favereau. ${ }^{7}$ Yet, the discussion leading to this volume con-

7 The conference, held in Jerusalem in 2016, was organised in the framework of the ERC project "Mobility, Empire and Cross-Cultural Contacts in Mongol Eurasia" led by Michal Biran, and funded by the European Research Council under the European Union's Seventh Framework Programme (FP/2007-13)/ERC Grant Agreement n.312397. 
tinued further after that, thanks to a series of follow-up meetings (the "Mongol Empire Spring Series"), aimed at promoting the dialogue among specialists of the four khanates, on topics which are central to the current scholarly debate on Mongol Eurasia. ${ }^{8}$ The aim of these meetings is to promote the dialogue and cooperation among specialists of the various languages and regions encompassing the Mongol Empire and its neighboring states, in order to achieve a more comprehensive understanding of the dynamics which shaped 13th and 14th century Eurasia.

What does this mean, concretely, for the study of Chinggisid diplomacy?

The present volume complements previous studies on the matter of Mongol diplomacy by innovatively combining case-studies from the United Mongol Empire to the four khanates (13th-14th centuries). A variety of languages, sources and cultural contexts are reviewed side by side, identifying similarities and differences in how Chinggisid diplomacy was practiced and narrated in the four corners of the Empire, and even beyond.

Comparison is achieved by analyzing the personnel, objects, words and narratives related to the diplomatic exchanges of the Mongols among themselves and with their neighbors in Europe and Asia. The picture resulting from these articles is that Mongol authority, as predicated by Chinggisid diplomacy, influenced Eurasia in many ways that go far beyond pure political domination or military contact. In the last decades a clear scholarly trend has developed, to understand the Mongol Empire and its aftermath by analysing its most important institutions (the kešig, i.e. "bodyguards", the jam i.e. "post-system", the army, the jasaq i.e. "law", the ortaq i.e. merchant "partnerships", etc.). As this volume shows, Chinggisid diplomacy was not only one of these fundamental institutions, but it also constituted the background against which the above-mentioned Mongol imperial practices interconnected and functioned together.

Further, debates around the Global Middle Ages often address issues of scale. ${ }^{9}$ Following this line of thought, the papers in this volume demonstrate how Chinggisid diplomacy, with its unprecedented system for travel and communication, with envoys, letters and objects crossing Eurasia from Japan to Europe, was one of the main expressions of a connected Eurasia under the

8 Further conferences were held on the topics of Mongol warfare (Sofia, 2017), Mongol Silk Roads (Szeged, 2018) and The Mongols and Religions (Vienna, 2019), the proceedings of all of which are in the course of publication.

9 One example is the analysis in Dudbridge, Glen, "Reworking the World System Paradigm", Past \& Present, CCXXxviII (suppl. 13; Nov. 2018): pp. 297-316. 
Mongols. In the 13th and 14th centuries, the methods of Mongol diplomacy, from marriage-alliances to gift exchanges, and its language of authority, from tenggeri to the jasaq, as well as the information about them, spread from Florentine chronicles to the letters of Vietnamese kings. Thus, it is exactly in the scale of how Chinggisid diplomacy resonated throughout the Medieval world that one can see how it truly contributed to Mongol globalization.

\section{Bibliographical References}

Aigle, Denise, "From 'Non-Negotiation' to an Abortive Alliance. Thoughts on the Diplomatic Exchanges between the Mongols and the Latin West", in Ead., The Mongol Empire between Myth and Reality (Leiden: Brill, 2014): pp. 159-98.

Aigle, Denise, "The Letters of Eljigidei, Hülegü and Abaqa - Mongol Overtures or Christian Ventriloquism?", Inner Asia, viI (2005): pp. 143-62.

Biran, Michal, "Diplomacy and chancellery practices in the Chagataid Khanate: some preliminary remarks", $O M$, LXXXVIII (2008): pp. 369-93.

Dudbridge, Glen, "Reworking the World System Paradigm", Past \& Present, ccxxxviII (suppl. 13, Nov. 2018): pp. 297-316.

Fiaschetti, Francesca, "Tradition, Innovation and the Construction of Qubilai's diplomacy", Ming Qing yanjiu, XVIII (2014): pp. 65-96.

Grigor'ev, Arkadiij Pavlovič, Mongol'skaja diplomatika XIII-XV vv: čingizidskie zhalovannye gramoty (Leningrad: Izdatel'stvo Leningradskogo universiteta, 1978).

Meyvaert, Paul, "An Unknown Letter of Hulagu, Il-Khan of Persia, to King Louis IX of France", Viator, XI (1980): pp. 245-59.

Sinor, Denis, "Diplomatic Practices in Medieval Inner Asia", in Bosworth, C.E., Issawi, C., Savory R., and A.L. Udovitch (eds.), Essays in honor of Bernard Lewis: the Islamic world from Classical to Modern Times (Princeton: The Darwin Press, 1989): pp. 337-55.

Skaff, Jonathan K., Sui-Tang China and Its Turko-Mongol Neighbors. Culture, Power, and Connections (Oxford: Oxford University Press, 2012 [Oxford Studies in Early Empires]).

Voegelin, Eric, "The Mongol Orders of Submission to European Powers, 1245-1255", Byzantion, XV (1940-1): pp. 378-413 = reprinted in a revised form, with English translation for all texts in: Sandoz, Ellis (ed.), Published Essays: 1940-1952 (Missouri: University of Missouri Press, 200o): pp. 76-125. 


\section{Biographical Note}

Francesca Fiaschetti teaches Inner and East Asian history at the History Department of the University of Vienna. Her research focuses on various aspects of cultural, diplomatic and military exchanges in Mongol Eurasia, history of Middle-period China, maritime Asia, and on Mongolian history and culture at large. 